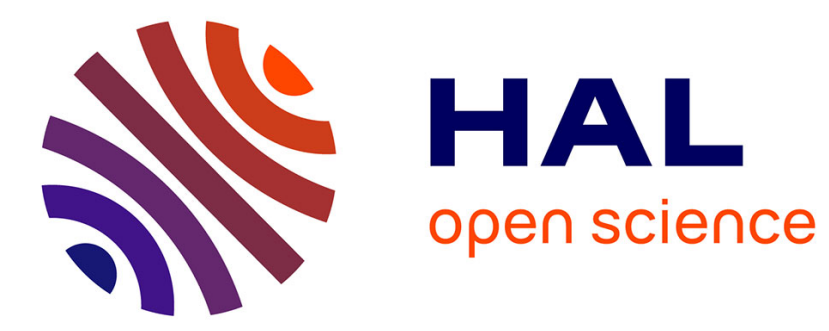

\title{
Silicic acid leakage from the Southern Ocean: Opposing effects of nutrient uptake and oceanic circulation
}

\author{
X. Crosta, C. Beucher, K. Pahnke, M. Brzezinski
}

\section{To cite this version:}

X. Crosta, C. Beucher, K. Pahnke, M. Brzezinski. Silicic acid leakage from the Southern Ocean: Opposing effects of nutrient uptake and oceanic circulation. Geophysical Research Letters, 2007, 34 (13), pp.n/a-n/a. 10.1029/2006GL029083 . hal-02329879

\section{HAL Id: hal-02329879 https://hal.science/hal-02329879}

Submitted on 16 Aug 2021

HAL is a multi-disciplinary open access archive for the deposit and dissemination of scientific research documents, whether they are published or not. The documents may come from teaching and research institutions in France or abroad, or from public or private research centers.
L'archive ouverte pluridisciplinaire HAL, est destinée au dépôt et à la diffusion de documents scientifiques de niveau recherche, publiés ou non, émanant des établissements d'enseignement et de recherche français ou étrangers, des laboratoires publics ou privés. 


\title{
Silicic acid leakage from the Southern Ocean: Opposing effects of nutrient uptake and oceanic circulation
}

\author{
X. Crosta, ${ }^{1}$ C. Beucher, ${ }^{2}$ K. Pahnke, ${ }^{3}$ and M. A. Brzezinski ${ }^{2,4}$ \\ Received 13 December 2006; revised 2 March 2007; accepted 14 May 2007; published 3 July 2007.
}

[1] Studies invoking the silicic acid leakage hypothesis to explain events of high biogenic opal deposition at low latitudes did not consider variations in formation rate of Southern Ocean intermediate waters. Comparison of $\delta^{30} \mathrm{Si}$ records from the Southern Ocean to records of biogenic opal accumulation from low-latitude upwelling systems indicates a strong negative correlation between the silicic acid content of Southern Ocean surface waters and opal deposition at low latitudes during the last $80 \mathrm{kyr}$ BP. This implies that $\mathrm{Si}$ leakage was somehow rendered ineffective when the silicic acid content of Southern Ocean waters was high. Comparison of opal accumulation records with records of intermediate water formation rates suggests that lower rates of intermediate water formation offset the higher silicic acid content of these water masses during glacial periods. This indicates that physical processes that control intermediate water transport dominate over biological processes that set the silicic acid content of Antarctic surface waters in determining the magnitude of silicic acid leakage from the Southern Ocean. Citation: Crosta, X., C. Beucher, K. Pahnke, and M. A. Brzezinski (2007), Silicic acid leakage from the Southern Ocean: Opposing effects of nutrient uptake and oceanic circulation, Geophys. Res. Lett., 34, L13601, doi:10.1029/ 2006GL029083.

\section{Introduction}

[2] The silicic acid leakage hypothesis (SALH), that may explain up to $60 \mathrm{ppm}$ of the glacial $\mathrm{pCO}_{2}$ drop [Matsumoto et al., 2002], proposes that lower silicic acid, $\mathrm{Si}(\mathrm{OH})_{4}$, and greater nitrate, $\mathrm{NO}_{3}^{-}$, utilization in Southern Ocean surface waters during glacial times increased the $\mathrm{Si}\left(\mathrm{OH}_{4}\right): \mathrm{NO}_{3}^{-}$ratio of waters escaping the Southern Ocean, thereby favoring the growth of diatoms over calcifying phytoplankton at low latitudes.

[3] The SALH is composed of two distinct parts that must each be validated. The first part involves biological processes in the Antarctic and Subantarctic zones whereby changes in the phytoplankton community from diatoms to non-siliceous organisms [Anderson et al., 2002] or changes in diatom physiology [e.g., Brzezinski et al., 2003] due to greater glacial dust input [Petit et al., 1999] act to decrease

\footnotetext{
${ }^{1}$ UMR 5805, Environnements et Paléoenvironnements Océaniques, Talence, France.

${ }^{2}$ Marine Science Institute, University of California, Santa Barbara, California, USA.

${ }^{3}$ Lamont-Doherty Earth Observatory, Columbia University, Palisades, New York, USA.

${ }^{4}$ Department of Ecology Evolution and Marine Biology, University of California, Santa Barbara, California, USA.
}

Copyright 2007 by the American Geophysical Union. 0094-8276/07/2006GL029083 silicic acid uptake leaving Antarctic Surface Waters (ASW) enriched in $\mathrm{Si}(\mathrm{OH})_{4}$ during glacial times [Brzezinski et al., 2002]. The second component of the SALH [Nozaki and Yamamoto, 2001; Matsumoto et al., 2002] is the incorporation of the Si-enriched ASW into SAMW and AAIW that flow northward propagating the changes occurring in the Southern Ocean to the thermocline region of low latitudes. The power of Southern Ocean intermediate waters to affect phytoplankton production on a global scale was recently affirmed by modelling studies that showed that the nutrients delivered by SAMW support three quarters of the marine primary productivity occurring north of $30^{\circ} \mathrm{S}$ latitude in the present day ocean including that occurring in the highly productive coastal upwelling regions off South Africa and South America [Sarmiento et al., 2004].

[4] Recent papers demonstrate that opal accumulation beneath low latitude upwelling systems in the Pacific was reduced during glacial periods [Pichat et al., 2004; Bradtmiller et al., 2006; Kienast et al., 2006] when the potential for Si leakage from the Southern Ocean was greatest (C. Beucher et al., Silicic acid dynamics in the glacial Subantarctic: Implications for the silicic acid leakage hypothesis, submitted to Global Biogeochemical Cycles, 2006, hereinafter referred to as Beucher et al., submitted manuscript, 2006). One possible explanation is that El Niño-like conditions during the last glacial in the equatorial Pacific Ocean may have reduced upwelling along the equator and in the eastern tropical Pacific sufficiently to counteract the effects of Si leakage [Bradtmiller et al., 2006, and references therein]. Alternatively, changes in circulation in the Southern Ocean may have truncated Si leakage at its source. Indeed, previous studies on the SALH and on its impact on glacial atmospheric $\mathrm{pCO}_{2}$ levels [Brzezinski et al., 2002; Matsumoto et al., 2002] did not consider variations in the formation rate of SAMW on glacial-interglacial timescale. However, changes in heat loss to the atmosphere [Karstensen and Quadfasel, 2002] and in surface salinity [Shin et al., 2003a, 2003b] during glacial periods may have altered SAMW and AAIW formation rates significantly. We here compare down-core records of $\mathrm{Si}(\mathrm{OH})_{4}$ utilization in ASW [De La Rocha et al., 1998; Beucher et al., submitted manuscript, 2006] to a set of down-core records of opal accumulation from low latitude upwelling regions [Romero et al., 2003; Pichat et al., 2004; Kienast et al., 2006], and to down-core records of SAMW and AAIW formation rates [Martinez, 1997; Pahnke and Zahn, 2005] to demonstrate that increases in the silicic acid content of Southern Ocean surface waters were offset by declines in the formation rate of intermediate waters, which would lessen the influence of silicic acid leakage from the Southern Ocean on opal production at low latitudes. The impact of reduced ventilation of Southern Ocean intermediate waters on atmospheric 


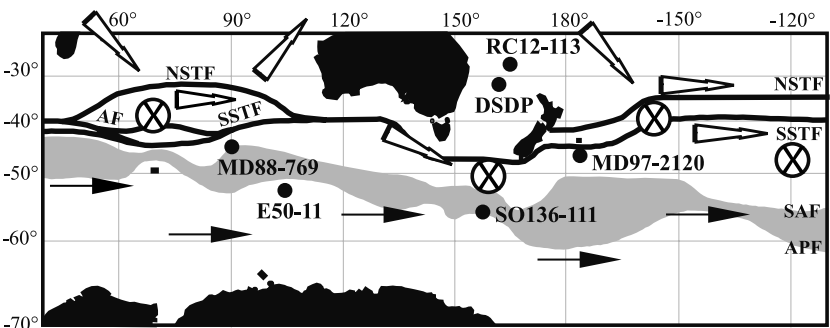

Figure 1. Location of the cores in relation to major hydrological fronts and water masses [Belkin and Gordon, 1996]. The Antarctic Zone (AZ) is located south of the Antarctic Polar Front; the Polar Front Zone (PFZ) is encompassed by the Antarctic Polar Front to the south and the Subantarctic Front to the north; the Subantarctic Zone (SAZ) is located between the Subantarctic Front and the Southern Subtropical Front; and the Subtropical Zone (STZ) is located north of the Southern Subtropical Front. APF = Antarctic Polar Front; SAF = Subantarctic Front; SSTF = southern Subtropical Front; NSTF = northern Subtropical Front; and $\mathrm{AF}=$ Agulhas Front. Black arrows depict the Antarctic Surface Waters flowing as part of the Antarctic Circumpolar Current. White arrows track the Subtropical Gyres circulation. Open circles with crosses indicate SAMW formation sites.

$\mathrm{pCO}_{2}$ levels is beyond the scope of this paper, in which we focus on the relationships between nutrient cycling in the Southern Ocean, ventilation of Antarctic intermediate waters and biological productivity at low latitudes.

\section{Material and Methods}

[5] The $\delta^{30} \mathrm{Si}$ records from Cores E50-11 (De La Rocha et al., 1998) and MD88-769 (Beucher et al., submitted manuscript, 2006) from the Antarctic and Subantarctic zones of the Indian sector of the Southern Ocean document relative $\mathrm{Si}(\mathrm{OH})_{4}$ utilization in $\mathrm{ASW}$, which serves as source waters for SAMW and AAIW (Figure 1). The $\delta^{30} \mathrm{Si}$ records from core RC13-259 from the Antarctic Atlantic [Brzezinski et al., 2002] is used to document silicic acid cycling on a longer time scale to better match the time scale of records of opal accumulation and intermediate water formation rates. That core is located in the Atlantic sector and thus it may provide slightly different interpretations on nutrient cycling. We here present the records as percent changes from the last glacial period to facilitate comparisons among records.

[6] Opal records from core GeoB3606-1 [Romero et al., 2003] and from cores ODP849, VNT01-8PC, TR136-19 and TR163-31 [Pichat et al., 2004; Kienast et al., 2006] are from the Lüderitz cell of the Benguela upwelling system (BUS) and the eastern equatorial Pacific upwelling (EEP), respectively. Both regions are under the influence of Southern Ocean intermediate waters [Sarmiento et al., 2004]. More precisely, the water that upwells in the BUS has two origins whereby less intense upwelling cells derive their water from the Atlantic Central water [Lutjeharms and Valentine, 1987] while more intense upwelling cells such as the Lüderitz cell derive their water from greater depths, i.e. SAMW and AAIW [Lutjeharms and Meeuwis, 1987]. The water that upwells in the EEP is mainly the lower branch of the Equatorial Under-Current that derives its nutrient content from the SAMW after transport as part of the New Guinea Coastal Under-Current [Toggweiler et al., 1991; Dugdale et al., 2002]. Si-rich source waters from the North Pacific conversely feed the upper branch of the Equatorial Under-Current that upwells in the Central Equatorial upwelling [Dugdale et al., 2002] minimizing the influence of the Southern Ocean on nutrient dynamics in this zone.

[7] Past variations in SAMW formation rates is deduced from the positive relationship between the percentage of $G$. truncatulinoides and the extent of the SAMW thermostad [Lohmann and Schweitzer, 1990]. It has been shown that $G$. truncatulinoides is a deep-dwelling species whose distribution is related to mode water thermostats (a term that indicates a thick layer of homogenous temperature). Higher percentages of this species indicate deeper thermostads and therefore more intense SAMW formation rates [Martinez, 1997]. Down-core records of G. truncatulinoides relative abundances are from the Tasman Sea (Figure 1), i.e. in the northward flow path of SAMW and AAIW toward its confluence with the New Guinea Coastal Under-Current.

[8] Past variations of AAIW formation rate is examined using the benthic foraminiferal carbon isotope ratio $\left(\delta^{13} \mathrm{C}_{\text {benth }}\right)$ of a mid-depth core from Chatham Rise, east of New Zealand (core MD97-2120) [Pahnke and Zahn, 2005]. The core is located in the northern Subantarctic Zone in the Southwest Pacific at a water depth of $1210 \mathrm{~m}$, near the

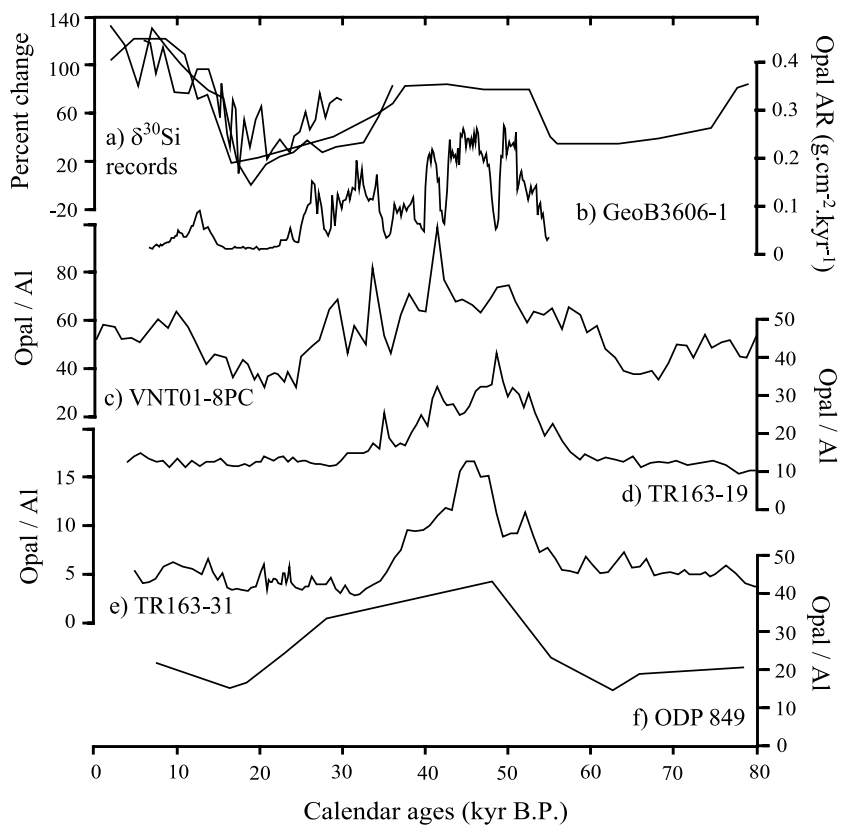

Figure 2. Records of $\delta^{30} \mathrm{Si}$ as percent change from the average value of the last glacial period (curve a) in cores E50-11 [De La Rocha et al., 1998], RC13-259 [Brzezinski et al., 2002] and MD88-769 (Beucher et al., submitted manuscript, 2006) from the Southern Ocean, and of biogenic opal accumulation (curves $\mathrm{b}-\mathrm{f}$ ) in cores GeoB3606-1 from the Benguela Upwelling System [Romero et al., 2003], VNT01-8PC, TR163-19, TR16331 and ODP site 849 from the eastern equatorial Pacific [Pichat et al., 2004; Kienast et al., 2006]. 


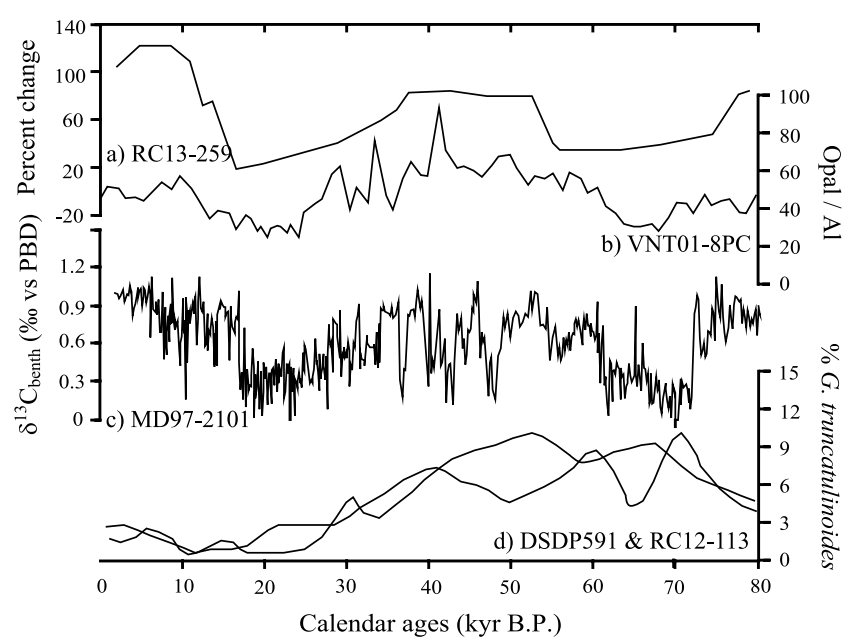

Figure 3. Records of $\delta^{30} \mathrm{Si}$ as percent change from the average value of the last glacial period in core RC13-259 (curve a), of biogenic opal accumulation in core VNT01$8 \mathrm{PC}$ from the eastern equatorial Pacific (curve b), of $\delta^{13} \mathrm{C}_{\text {benth }}$ in core MD97-2101 from the northern Subantarctic Zone (curve c) [Pahnke and Zahn, 2005], and of relative abundances of the deep-living foraminifera Globorotalia truncatulinoides in cores RC12-113 and DSDP site 591 from the northern Tasman Sea (curve d) [Martinez, 1997].

present-day lower depth limit of the AAIW core layer (Figure 1), which makes it ideally located to track past changes in AAIW flux. The $\delta^{13} \mathrm{C}_{\text {benth }}$ signature is derived from $\delta^{13} \mathrm{C}$ of total dissolved inorganic carbon in the ocean that is controlled by biological nutrient cycling and water mass chemical aging [Kroopnick, 1985]. This makes $\delta^{13} \mathrm{C}_{\text {benth }}$ a valuable proxy to reconstruct past water mass variability when changes in preformed nutrient concentration in the source region are constrained. Changes in preformed nutrient concentration in the Subantarctic source region should be reflected in planktonic $\delta^{13} \mathrm{C}$ records from these areas [Spero and Lea, 2002], which strongly correlate with the planktonic $\delta^{13} \mathrm{C}$ record of core MD97-2120. These planktonic $\delta^{13} \mathrm{C}$ records show no obvious correlation with the benthic mid-depth $\delta^{13} \mathrm{C}$ record, demonstrating that preformed $\delta^{13} \mathrm{C}$ changes are not responsible for the $\delta^{13} \mathrm{C}_{\text {benth }}$ variations on Chatham Rise. More details on the core stratigraphies, on the protocols used to reconstruct the different records and on rationales of each proxy can be found in the original papers.

\section{Results and Discussion}

[9] Between 25-16 kyr B.P., during the last glacial period, depleted $\delta^{30} \mathrm{Si}$ values demonstrate low relative $\mathrm{Si}(\mathrm{OH})_{4}$ utilization (Figure 2, curve a) while enriched $\delta^{15} \mathrm{~N}_{\text {diat }}$ values indicate strong $\mathrm{NO}_{3}^{-}$utilization [Crosta et al., 2005]. The glacial $\mathrm{Si}(\mathrm{OH})_{4}: \mathrm{NO}_{3}^{-}$uptake ratio was therefore low, which resulted in high $\mathrm{Si}(\mathrm{OH})_{4}: \mathrm{NO}_{3}^{-}$ratio in ASW. The situation was reversed during the Holocene and the MIS 3 with strong $\mathrm{Si}(\mathrm{OH})_{4}$ and low $\mathrm{NO}_{3}^{-}$relative utilization leaving the surface waters depleted in $\mathrm{Si}(\mathrm{OH})_{4}$ relative to $\mathrm{NO}_{3}^{-}$. This pattern was valid both for the Antarctic Zone and for the Subantarctic Zone [Crosta et al., 2005; Robinson et al., 2005; Beucher et al., submitted manuscript, 2006]. Based on a simple $\delta^{30} \mathrm{Si}$ isotope mass balance model, Beucher et al. (submitted manuscript, 2006) estimate that silicic leakage was nearly three times greater during the last glacial period compared to the Holocene, $21 \mu \mathrm{M}$ and $8 \mu \mathrm{M}$ respectively. Their $\delta^{30} \mathrm{Si}$ records show that $\mathrm{Si}(\mathrm{OH})_{4}$ cycling was similar during the 55-25 kyr BP period and the Holocene (Figure 2, curve a). The silicic acid content of intermediate waters during MIS 3 was therefore certainly reduced compared to the last glacial.

[10] Records of biogenic opal accumulation in the BUS and the EEP (Figures 2, curves $\mathrm{b}-\mathrm{f}$ ) are strongly inversely correlated with the $\delta^{30} \mathrm{Si}$ records over the last $80 \mathrm{kyr}$ BP. Maximum biogenic opal deposition occurs during MIS 3 when the $\mathrm{Si}(\mathrm{OH})_{4}$ content of intermediate waters was low. Conversely, very low biogenic opal deposition is found during the last glacial period when the $\mathrm{Si}(\mathrm{OH})_{4}$ content of intermediate waters was maximal (Beucher et al., submitted manuscript, 2006). This relationship is less clear during the Holocene, with some records showing low opal burial (Figure 2, curves b, $\mathrm{d}$ and e) as expected from the implied $\mathrm{Si}(\mathrm{OH})_{4}$ content of intermediate waters, while other records show relatively high deposition [Bradtmiller et al., 2006] (Figure 2, curves c and f). Considering the entire $80 \mathrm{kyr}$ record, it is clear that silicic acid content in Southern Ocean intermediate waters alone cannot drive patterns of opal deposition in low latitude upwelling systems. Other processes must moderate the effect of changes in the $\mathrm{Si}(\mathrm{OH})_{4}$ content of intermediate waters.

[11] We suggest that changes in the flux of SAMW and AAIW escaping the Southern Ocean and in their upwelling at low latitudes played a greater role in determining low latitude diatom production than did the silicic acid content of these water masses. To support this hypothesis, we compared records of $\delta^{30} \mathrm{Si}$ and biogenic opal deposition to records of AAIW and SAMW formation rates. There is a negative correlation between the $\mathrm{Si}(\mathrm{OH})_{4}$ content in ASW (Figure 3, curve a) and AAIW formation rate (Figure 3, curve c) over the last $80 \mathrm{kyr}$ BP. High nutrient content in ASW during 25-16 kyr BP and 70-60 kyr BP coincided with periods of reduced AAIW formation as inferred from depleted $\delta^{13} \mathrm{C}_{\text {benth }}$ values. Conversely, low silicic acid content during 55-25 kyr BP coincided with more intense AAIW formation rates as indicated by enriched $\delta^{13} \mathrm{C}_{\text {benth }}$ values. This demonstrates that changes in nutrient cycling that favoured the Si-enrichment of ASW were counterbalanced by reductions in the intensity of intermediate water formation. In contrast, biogenic accumulation (Figure 3, curve b) was positively correlated with AAIW formation rate (Figure 3, curve c) over the last $80 \mathrm{kyr}$ BP. Low opal deposition events during 25-16 kyr BP and 70-60 kyr BP coincided with periods of reduced AAIW formation rate while high opal deposition during 55-25 kyr BP was synchronous with more intense rates of AAIW formation.

[12] Records of relative abundances of G. truncatulinoides from the northern Tasman Sea provide some insight on past variations in SAMW dynamics [Martinez, 1997]. These records show high relative abundances during the 70-40 kyr BP period (Figure 3, curve d) when greatest opal burial is found in low latitude upwelling systems (Figure 3, curve b) and low relative abundances since $30 \mathrm{kyr} B P$, in agreement with low opal deposition at this time. This 
relation does not hold during MIS 4, when G. truncatulinoides abundances are high, but opal accumulation at low latitudes is low. If AAIW formation was strongly reduced at this time, as suggested by mid-depth $\delta^{13} \mathrm{C}_{\text {benth, }}$ it may account for decreased productivity at low latitudes.

[13] Given the generally low $\mathrm{Si}(\mathrm{OH})_{4}$ content of intermediate waters, it is possible that intense fluxes of both SAMW and AAIW are necessary to supply enough silicic acid to support diatom production in low latitude environments as both water masses feed low latitude upwelling. Lutjeharms and Valentine [1987] and Lutjeharms and Meeuwis [1987] showed that more intense upwellings draw water from greater depths. Based on grain size analysis, Pichevin et al. [2005] suggest greater trade-wind activity off southwest Africa and greater BUS intensity during the 70$30 \mathrm{kyr}$ BP period. After $30 \mathrm{kyr} \mathrm{BP}$, decreasing wind strength and resulting upwelling intensity may have shifted the origin of the upwelled water from AAIW to SAMW. It is accepted that the main nutrient supply to these upwelling zones today is SAMW [Sarmiento et al., 2004], but there is currently no data to suggest that this was the case in the past.

[14] Antarctic Intermediate Water is formed by the northward advection of fresh and cool ASW and cross-frontal sinking at the Subantarctic Front, after which this water mass flows northward at depths between 800-1200m [Sloyan and Rintoul, 2001]. Reduction in the rate of AAIW formation during the last glacial period may be linked to homogenisation of surface water density gradients across the Polar Frontal Zone [Shin et al., 2003a, 2003b] as a result of increased meltwater in the Antarctic and southern Subantarctic zones because of an enhanced seasonal sea ice cycle [Gersonde et al., 2005]. Indeed, modelling studies demonstrate that greater Ekman-driven injection of fresher and cooler ASW into the Subantarctic Zone during glacial periods results in a strong freshening and lightening of surface and subsurface waters to depth of $1000 \mathrm{~m}$ deep north of $50-45^{\circ} \mathrm{S}$ consistent with a lower AAIW formation rate during glacial times [Shin et al., 2003a, 2003b]. The good agreement between the diatom-based SST records and the $\delta^{13} \mathrm{C}_{\text {benth }}$ record (Figure 2) additionally confirms the link between Antarctic sea-surface conditions and AAIW formation [Pahnke and Zahn, 2005].

[15] Subantarctic Mode Waters are formed on the equatorward side of the Antarctic Circumpolar Current by deep mixing of warm and salty Subantarctic Surface Waters in winter [McCartney, 1977]. The ocean-to-atmosphere thermal gradient, which determines the amount of heat loss from the ocean and therefore the increase in density, is a key process forming SAMW [Karstensen and Quadfasel, 2002]. Subantarctic Mode Waters are transported northward on top of AAIW at depths between 400-800m [Trull et al., 2001]. It is not clear why SAMW formation rate does not seem to follow climatic cycles. Although the decreasing trend in SAMW fluxes during the last $60 \mathrm{kyr}$ may be related to reduction of the thermal gradient between the ocean and the atmosphere and to injection of low salinity surface waters into the southern Subantarctic Zone, it is surprising that SAMW fluxes are low during the Holocene when one would expect greater formation rates due to greater heat loss to the atmosphere and presence of more salty surface waters. Better records of SAMW formation rate are needed to better understand SAMW past history and to document possible shifts in intermediate waters dominance into supplying nutrients to low latitudes.

\section{Conclusion}

[16] We show that biogenic silica accumulation in low latitude regions of the Southern hemisphere have been influenced by shifts in the rate of formation of Antarctic intermediate waters over the past $80 \mathrm{kyr}$ BP. Highest opal accumulation in low latitude upwelling systems occurred when the rate of formation of AAIW and SAMW were strong, but when their silicic acid content was relatively low. Conversely, low silica burial occurred during periods of high $\mathrm{Si}(\mathrm{OH})_{4}$ concentration in intermediate waters, but of weak AAIW and SAMW formation rates. Despite some limitations inherent to the distribution of the cores examined, our investigation suggests for the first time that $\mathrm{Si}$ leakage and its impact on siliceous phytoplankton production at low latitudes was strongly dependent on the flux of intermediate waters escaping the Southern Ocean. Biological processes occurring in the Southern ocean, though important in controlling the $\mathrm{Si}(\mathrm{OH})_{4}: \mathrm{NO}_{3}^{-}$ratio of intermediate waters, may be less important than changes in oceanic circulation in driving low latitude diatom productivity.

[17] Our findings suggest that declines in intermediate water flux significantly affect the biological production in low latitude upwelling system. The impact on past atmospheric $\mathrm{CO}_{2}$ levels is less clear as atmospheric $\mathrm{pCO}_{2}$ concentrations are greatly dependent on ocean alkalinity which is in turn linked to the carbonate-to-organic carbon ratio. The reaching of our hypothesis on atmospheric $\mathrm{pCO}_{2}$ concentrations needs to be quantified through model experiments in which intermediate waters flux is allowed to decline synchronously as the $\mathrm{Si}(\mathrm{OH})_{4}: \mathrm{NO}_{3}^{-}$ratio of $\mathrm{ASW}$ increases.

[18] Acknowledgments. We thank K. Matsumoto and I. Belkin, H.-Y. Park, and L. Dézileau for constructive discussions. We thank I. Martinez, S. Kienast, S. Pichat, and O. Romero for data. We also thank Jorge Sarmiento and another unknown reviewer for comments that improved the manuscript. Financial support for this study was provided by CNRSPNEDC, and IPEV-TAAF and the US NSF. This is EPOC contribution 1661.

\section{References}

Anderson, R. F., Z. Chase, M. Q. Fleischer, and J. Sachs (2002), The Southern Ocean's biological pump during the Last Glacial Maximum, Deep Sea Res., Part II, 49, 1909-1938.

Belkin, I. M., and A. Gordon (1996), Southern Ocean fronts from the Greenwich meridian to Tasmania, J. Geophys. Res., 101(C2), 36753696.

Bradtmiller, L. I., R. F. Anderson, M. Q. Fleisher, and L. H. Burckle (2006), Diatom productivity in the equatorial Pacific Ocean from the last glacial period to the present: A test of the silicic acid leakage hypothesis, $\mathrm{Pa}$ leoceanography, 21, PA4201, doi:10.1029/2006PA001282.

Brzezinski, M. A., C. J. Pride, V. M. Franck, D. M. Sigman, J. L. Sarmiento, K. Matsumoto, N. Gruber, G. H. Rau, and K. H. Coale (2002), A switch from $\mathrm{Si}(\mathrm{OH})_{4}$ to $\mathrm{NO}_{3}^{-}$depletion in the glacial Southern Ocean, Geophys. Res. Lett., 29(12), 1564, doi:10.1029/2001GL014349.

Brzezinski, M. A., M. L. Dickson, D. M. Nelson, and R. Sambrotto (2003), Ratio of Si, C, and N uptake by microplankton in the Southern Ocean, Deep Sea Res., Part II, 50, 619-633.

Crosta, X., A. Shemesh, J. Etourneau, R. Yam, I. Billy, and J. J. Pichon (2005), Nutrient cycling in the Indian sector of the Southern Ocean over the last 50,000 years, Global Biogeochem. Cycles, 19, GB3007, doi:10.1029/2004GB002344.

De la Rocha, C. L., M. A. Brzezinski, M. J. DeNiro, and A. Shemesh (1998), Silicon-isotope composition of diatom as an indicator of past oceanic change, Nature, 395, 680-683. 
Dugdale, R. C., A. G. Wischmeyer, F. P. Wilkerson, R. T. Barber, F. Chai, M. S. Jian, and T. H. Peng (2002), Meridional asymmetry of source nutrients to the equatorial Pacific upwelling ecosystem and its potential impact on ocean-atmosphere $\mathrm{CO}_{2}$ flux; a data and modelling approach, Deep Sea Res., Part II, 49, 2513-2531.

Gersonde, R., X. Crosta, A. Abelmann, and L. Armand (2005), Sea surface temperature and sea ice distribution of the Southern Ocean at the EPILOG Last Glacial Maximum-A circum-Antarctic view based on siliceous microfossil records, Quat. Sci. Rev., 24, 869-896.

Karstensen, J., and D. Quadfasel (2002), Formation of southern hemisphere thermocline waters: Water mass conversion and subduction, J. Phys. Oceanogr., 32, 3020-3038.

Kienast, S. S., M. Kienast, S. Jaccard, S. E. Calvert, and R. François (2006), Testing the silica leakage hypothesis with sedimentary opal records from the eastern equatorial Pacific over the last 150 kyrs, Geophys. Res. Lett., 33, L15607, doi:10.1029/2006GL026651.

Kroopnick, P. (1985), The distribution of ${ }^{13} \mathrm{C}$ of $\Sigma \mathrm{CO}_{2}$ in the world oceans, Deep Sea Res., Part A, 32, 57-84.

Lohmann, G. P., and P. N. Schweitzer (1990), Globorotalia truncatulinoides growth and chemistry as probes of the past thermocline: 1 . Shell size, Paleoceanography, 5, 55-75.

Lutjeharms, J. R. E., and J. M. Meeuwis (1987), The extent and variability of south-east Atlantic upwelling, in The Benguela and Comparable Ecosystems, S. Afr. J. Mar. Sci., vol. 5, edited by A. I. L. Payne, J. A. Gulland, and K. H. Brink, pp. 51-62, Sea Fish. Res. Inst., Cape Town, South Africa.

Lutjeharms, J. R. E., and H. R. Valentine (1987), Water types and volumetric considerations of the south-east Atlantic upwelling regime, The Benguela and Comparable Ecosystems, S. Afr. J. Mar. Sci., vol. 5, edited by A. I. L. Payne, J. A. Gulland, and K. H. Brink, pp. 63-71, Sea Fish. Res. Inst., Cape Town, South Africa.

Martinez, J. I. (1997), Decreasing influence of Subantarctic Mode Water north of the Tasman Front over the past $150 \mathrm{kyr}$, Palaeogeogr. Palaeoclim. Palaeoecol., 131, 355-364.

Matsumoto, K., J. L. Sarmiento, and M. A. Brzezinski (2002), Silicic acid leakage from the Southern Ocean: A possible explanation for glacial atmospheric $p \mathrm{CO}_{2}$, Global Biogeochem. Cycles, 16(3), 1031, doi:10.1029/2001GB001442.

McCartney, M. S. (1977), Subantarctic Mode Water, Deep Sea Res., 24, $103-119$.

Nozaki, Y., and Y. Yamamoto (2001), Radium 228 based nitrate fluxes in the eastern Indian Ocean and the South China Sea and a silicon-induced "alkalinity pump" hypothesis, Global Biogeochem. Cycles, 15(3), 555568.

Pahnke, K., and R. Zahn (2005), Southern Hemisphere water mass conversion linked with North Atlantic climate variability, Science, 307, 17411746.
Petit, J. R., et al. (1999), Climate and atmospheric history of the past 420.000 years from the Vostok ice core, Antarctica, Nature, 399, 429436.

Pichat, S., K. W. W. Sims, R. François, J. F. McManus, S. Brown Leger, and F. Albarède (2004), Lower export production during glacial periods in the equatorial Pacific derived from $\left({ }^{231} \mathrm{~Pa} /{ }^{230} \mathrm{Th}\right)_{\mathrm{xs}, 0}$ measurements in deep-sea sediments, Paleoceanography, 19, PA4023, doi:10.1029/ 2003PA000994.

Pichevin, L., P. Martinez, P. Bertrand, R. Schneider, J. Giraudeau, and K. Emeis (2005), Nitrogen cycling on the Namibian shelf and slope over the last two climatic cycles: Local and global forcings, Paleoceanography, 20, PA2006, doi:10.1029/2004PA001001.

Robinson, R. S., D. M. Sigman, P. J. DiFiore, M. M. Rohde, T. A. Mashiotta, and D. W. Lea (2005), Diatom-bound ${ }^{15} \mathrm{~N} /{ }^{14} \mathrm{~N}$ : New support for enhanced nutrient consumption in the ice age subantarctic, Paleoceanography, 20, PA3003, doi:10.1029/2004PA001114.

Romero, O., G. Mollenhauer, R. R. Schneider, and G. Wefer (2003), Oscillation of the siliceous imprint in the central Benguela upweling system from MIS 3 through to Early Holocene: The influence of the Southern Ocean, J. Quat. Sci., 18(8), 733-743.

Sarmiento, J. L., G. Gruber, M. A. Brzezinski, and J. P. Dunne (2004), High-latitude controls of thermocline nutrients and low latitude biological productivity, Nature, 427, 56-60.

Shin, S. I., Z. Liu, B. L. Otto-Bliesner, E. C. Brady, J. E. Kutzbach, and S. P. Harrison (2003a), A simulation of the Last Glacial Maximum climate using the NCAR-CCSM, Clim. Dyn., 20, 127-151.

Shin, S., Z. Liu, B. L. Otto-Bliesner, J. E. Kutzbach, and S. J. Vavrus (2003b), Southern Ocean sea-ice control of the glacial North Atlantic thermohaline circulation, Geophys. Res. Lett., 30(2), 1096, doi:10.1029/ 2002GL015513.

Sloyan, B. M., and S. R. Rintoul (2001), Circulation, renewal, and modification of Antarctic mode and intermediate water, J. Phys. Oceanogr., $31,1005-1030$.

Spero, H. J., and D. W. Lea (2002), The cause of carbon isotope minimum events on glacial terminations, Science, 296, 522-525.

Toggweiler, J. R., K. Dixon, and W. Broeker (1991), The Peru upwelling and the ventilation of the South Pacific thermocline, J. Geophys. Res., 96, 20,467-20,497.

Trull, T., S. R. Rintoul, M. Hadfield, and E. R. Abraham (2001), Circulation and seasonal evolution of polar waters south of Australia: Implications for iron fertilization of the Southern Ocean, Deep Sea Res., Part II, 48 , $2439-2466$.

C. Beucher and M. A. Brzezinski, Marine Science Institute, University of California, Santa Barbara, CA 93106, USA.

X. Crosta, UMR 5805, EPOC, Talence Cedex F-33405, France. (x.crosta@epoc.u-bordeaux1.fr)

K. Pahnke, Lamont-Doherty Earth Observatory, Columbia University, Palisades, NY 10964, USA. 